\title{
A Practical Education Training Model as A Memorizing Effort to the Rating of Diversity
}

\author{
Roswita Sitompul \\ Faculty of Law \\ University Of Islam Sumatera Utara \\ Medan, Indonesia \\ Roswita_sitompul@yahoo.com
}

\author{
Alesyanti and Ahmad Fauzi \\ Faculty of Law \\ University of Muhammadiyah Sumatera Utara \\ Medan, Indonesia
}

\begin{abstract}
At the time human age has begun to mature, one starts to consolidate the steps that must be taken in the work affairs, fostering the family, and as members of the community. The action will become a lifestyle that will be his trademark in doing things. An early adult usually has a desire to marry and nurture a family beginning at the beginning of adulthood. But the desire to marry is not accompanied by enough preparation for the bride, especially his mental and psychological preparations so that the impact of divorce easily. Divorce data obtained from the Ministry of Religious Affairs, in 2011 recorded as many as $2,118,130$ people married and as many as 324,527 people divorces. If averaged in 1 day happened 954 cases of divorce. The high number of divorces also occurred in the Medan city. Within one day, as much as $\mathbf{7 0 \%}$ divorce occurred due to wife's lawsuit against a husband. It is, therefore, necessary to provide an integrated, permanent and sustainable handling of pre-marriage practical training. Pre-marriage useful training materials should be a designed so that the content indicator can fill all the required elements of a couple before stepping into a marriage. Research and development method test this model. Target, in particular, resulted in a practical training model of pre-marriage education program as an effort to minimize high divorce rate in Medan City, which can be used by Ministry of Religious Affairs and Office of Religious Affairs in anticipation of the high divorce rate in Medan city.
\end{abstract}

Keywords- divorce, pre-marriage practical training, and marriage

\section{INTRODUCTION}

The high number of divorce cases occurring in Indonesia in recent years is unfortunate many parties. Especially if you see the Indonesian nation as a religious nation. The disharmony that occurs between

husband and wife allegedly arise due to poor communication that entwined when already running a marriage relationship. Related to the number of young couples who divorced it because they enter the marriage is not ready mentally, psychologically and socially, "

North Sumatra Province continues to increase every year. Divorce or wife suits dominate divorce cases. During 2015, the Medan Class Religion Court handled about 3,000 cases, and 80 percent of them involved domestic disputes or divorce issues. "Most of those who filed for divorce are young, age 30.
New marriages continue to divorce also many," said Registrar of High Court of Religious Affairs Medan Syarwani to Republika.co.Id, Monday (3/10).

In 2014, 10,429 divorce cases were resolved in 20 Religious Courts in the Medan High Court area. This number is increasing by 2015 , with 10,834 cases being resolved. For 2016, until August, 6,653 divorce cases were cut off throughout the Religious Courts of North Sumatra. And Medan City ranks highest for divorce cases

Divorce rates are always increasing every year. Most cases of divorce are divorce cases from the wife. The cause of the high divorce rate in some areas in Indonesia is the husband is not responsible, the man does not provide a living, the husband is less able to run his role as a husband and father for his children, husband, and wife less understand the roles and responsibilities of each, psychological, biological, third-party, and economic difficulties. The influence of media that expose cases of domestic conflicts and divorce among public figures, whether consciously or unconsciously, has a negative impact on society, so the strengthening of marriage institutions is a necessity in development (Sugandi, 2008).

Institutionally, marriage is the birth and emotional bond of a man and a woman to a married couple that aims to form a family. The bond must meet the requirements of the marriage law. Also, these men and women have rights and duties that must be exercised while bound in a marriage.

Every couple who has a sense of attraction and compatibility wants a marriage bond. The desire to marry and meet the goals and needs of marriage usually begins to occur in someone who entered early adulthood. Early adulthood begins at age 18 to about age 40, when the physical and psychological changes that accompany the psychological abilities (Hurlock, 1991).

Early adulthood is a period of adjustment to new patterns of new social and social life. Early adults are expected to play new roles such as the role of spouse, parent, and breadwinner. The development of new attitudes, desires, and new values according to this task is demanded by society towards the early adulthood (Dinar, 2007)

In early adulthood, a person begins to consolidate the steps that must be taken in the work affairs, fostering the family, and as members of the community. The step will 
become a lifestyle that will be his trademark in doing things. An early adult usually has a desire to marry and nurture a family beginning in early adulthood. However, they are also preoccupied with work affairs that require extra energy.

This cased them to have less time to prepare for marriage regarding mental and psychological. Whereas the early adults need information about the intricacies of marriage as the provision in marriage to achieve the goals of marriage. Therefore, the early adult who will enter the marriage needs to get the right information, and it does not take much time. This case is to avoid the many problems that often occur in marriage such as adjustment with spouse, sexual adjustment, financial adjustment, and adjustment with partner's family (Hurlock, 1991).

\section{Pre-Marriage EducAtion}

\section{A. Selecting a Template (Heading 2)}

First, confirm that you have the correct template for your paper size. This template has been tailored for output on the A4 paper size. If you are using US letter-sized paper, please close this file and download the file "MSW_USltr_format".

\section{B. Maintaining the Integrity of the Specifications}

Pre-marriage course materials such as reproductive health programs on maternal health care during pregnancy, childbirth, the importance of family planning programs, sharia law on marriage in Islam, such as cleaning large and small accounts, financial management to be able. Also, the material is how to educate children to stay healthy, intelligent and creative, and socialize Law No. 10/1974 on Marriage, Law against Domestic Violence (KDRT), and understanding of family functions, such as family, welfare, social and economic resilience.

Couples who will marry need to have a mature stock before marriage is the provision of knowledge to suffice what will be done after marriage later. Such arrangement can be obtained through pre-marital education or some short course that provides education on how to perform parenting duties efficiently and functionally (Usman, 1998). Training can be one alternative model of education for couples to be married.

A good training program is a training program that can increase the knowledge and skills of the participants. Based on the above opinion can be concluded that the training can improve the skills, knowledge, insight, learning, and experience for members who follow these activities. Training will also fulfill one's curiosity about the information they need.

In a marriage, everyone desires a happy, eternal, and prosperous home life, by the purpose of marriage contained in Law No. 1 of 1974. However, not everyone can form a family that aspires to it, this due to divorce, either divorce is dead, divorce talaq, or divorce over the judge's verdict.

Divorce is the breaking of the marriage bond between a man and a woman as a husband and wife, conducted before a court of law, namely the District Court for non-Muslims and the Religious Courts for Muslims. While the definition of divorce according to civil law is the abolition of marriage with the judge's decision on the demands of one party in the wedding (Achmad, D 1990: 65).

Nawawi (1997) said that education is a process of providing assistance for workers to master special skills or help to correct their shortcomings in performing the work. The focus of its activities is to improve workability in meeting the needs of today's most effective way of working. While the practical meaning is, that the learned citizens who have been trained to apply the ability immediately so it must come in handy, (Tjiptono \& Diana, 1998).

\section{MODEL RESEARCH AND DEVELOPMENT}

This research was conducted using Research and Development Model with survey method descriptive quantitative analysis does data processing technique. The Research and Development model is the basis for developing the products to be produced, with questionnaire instruments, interviews, documentation and archive studies. Young adolescents who attended prenuptial education program and became the target of 45 people who live in Medan.The sample was taken 45 people with purposive sampling technique. The fundamental consideration of sampling: the number of instructors five people, the effectiveness ratio of a training program 1: 10 , it means one instructor is guiding 10 participants. Because of the advantages of 5 members, the last 1 group conducted 5 participants, from five pre-marriage training materials, experts taught each component in their respective fields.

\section{ANALYZE AND RESUlts}

\section{A. Pre-marital training model used in the Ministry of Religious City of Medan.}

If you look at the dimensions needed for the integrity of a household, that is religion, social, and religion, marriage certainly requires a variety of readiness so that marriage is done with proper planning. In Indonesia there is no necessity for a married man, to go through a pre-marriage preparation. The Ministry of Religion has indeed provided such containers, but only a few couples follow. Based on the observation of the researchers, those who undergo practical pre-marriage training as well as not interested, because they only leave the event even though it has not ended. A situation more sad, because of the Ministry of Religion there is no necessity for those who will register for marriage, must get a certificate has been through the preparation of pre-marriage, The tendency of premarriage practice methods that are only legal-formal need to be evaluated immediately, because pre-marriage courses implemented in a short time only one day (9:00 to 16:00 hours), so what is the purpose of pre-marriage courses is the creation of knowledge and understanding of the bride less than the maximum and pre-marriage targeted as an effort to reduce the rate of divorce, it seems difficult to be realized.

Pre-marriage courses conducted in the ministry of a religion of Medan is a preventive measure to minimize the occurrence of problems in the household at a later date. Class Candidate a bridge (catin) is a provision of knowledge, 
understanding, and skill in a short time to catin (prospective bride) about life household/family. The purpose of this rule is to increase understanding and knowledge of family/household life in realizing family saqînah, as well as reducing disputes, divorce, and domestic violence.

The competent organizer for the implementation of the Catin Course is the Advisory, Counseling, and Guardianship (BP4) Advisory Board or other accredited bodies and agencies accredited by the Ministry of Religion. Catin Course materials are provided for at least 24 hours of instruction delivered by resource persons consisting of marriage and family consultants expertise possessed with methods of preaching, dialogue, simulation, and case studies. The material covers marriage procedures and procedures, religious knowledge, marriage and family law, marital rights and duties, reproductive health, family management and marital and family psychology. Facilities for Catin Course such as syllabus, module, certification of pass participants, and other infrastructure are provided by the Ministry of Religious Affairs. Pass mark certificate, proof of graduation following Pre-Marriage Courses is a requirement of marriage registration.

\section{B. Development of pre-marital education training model offered.}

From the questionnaire implementation, the researcher was able to formulate an early model in the form of premarital course curriculum design.

\section{Results expected by the use of practical training model of prenuptial education}

The above model is a mixture of materials that have been employed in the ministry of a religion of Medan city and the content expected by the participants pre-marriage courses, the researcher's tabulation of the questionnaire results answered participants. And expected model above, be an alternative for efforts to minimize the high rate of divorce in the city of Medan. This model will be effective in reducing the divorce rate if every married age couple is required to attend premarriage training and must get a pass certificate before being permitted to marry. Through this stage of the model is expected married couples can foster real families and empower families to be able to improve the quality of marriage. Therefore consultants and practitioners of marriage should be able to provide counseling or seminars that see the problems from various sides of psychology, sexology, law, and religion (Dinar, 2007).

Given the ineffectiveness of pre-marriage courses in reducing the high rate of divorce in Medan City, the first step can be taken, increasing the competence and number of officers in KUA, and cooperation with ministries of religion is not only formal but more collaborative evaluation of the program; resource persons or speakers in accordance with their third expertise, extending the duration of the pre-marriage course, observation during the study, pre-marital course preparation at the Medan municipality ministry for only 8 hours (9.00-16.00), this is certainly ineffective and efficient. Fourth, to cooperate with relevant agencies or parties with the objective of finding the best format to solve the problems that are faced, such as the bonds of Indonesian scholars, Islamic organizations and other related institutions. It is also necessary to cooperate with private parties who have pre-marriage training courses as partners and fifth, add material problem solver, this material aims to provide an understanding of the solution for the husband and wife when experiencing problems in the household one day. The depth of this material is given by case analysis method.

\section{CONCLUSION}

Divorce should be avoided, permissible acts but hated by religion. Islam forbids women from filing for divorce, but the phenomenon in the religious court of Medan city, that's exactly what happened. Effective implementation of pra.nikah practical training, review of materials, methods, and learning media. Pre-marriage practical training model is expected to reduce the high rate of divorce in the city of Medan.

\section{REFERENCES}

[1] Achmad, Djumairi. S.H. 1990.Hukum Perdata II. Semarang: Dosen Fakultas Syari'ah IAIN Walisongo.

[2] Analisa. 2017. Ketidakmatangan pernikahan beresiko perceraian. Medan

[3] Dinar. 2007. Program Pelatihan Pranikah bagi Pasangan Usia Dewasa Awal. Tesis. Fakultas Psikologi. Universitas Muhammadiyah Surakarta.

[4] http://harian .analisadaily. com/kota/ news/kajian -pranikah- dapatmengantisipasi- angka- perceraian/185121/2015/11/03

[5] Hurlock, E.B. 1991. Psikologi Perkembangan edisi kelima : Suatu Pendekatan Sepanjang Rentang Kehidupan. Jakarta : Penerbit Erlangga.

[6] Nawawi, H. 1997. Manajemen Sumber Daya Manusia. Yogyakarta, Gajah Mada Universitas Press.

[7] Sugandi. 2008. Konseling Pra Nikah bagi Mahasiswa di Perguruan Tinggi Melalui Pendekatan kelompok. UPI - Bandung

[8] Supadi. 2007. Tingkat Kesadaran Hukum Tentang Perceraian Bagi Isteri (Studi Kasus Tentang Cerai Gugat di Kecamatan Tengaran). Skripsi : Sekolah Tinggi Agama Islam Negeri (STAIN) Salatiga

[9] Tjiptono, F dan Diana, A, 1998. Total Quality, Management, Yogyakarta : Andi offset.

[10] Usman Y. 1998. Pembangunan dan Pemberdayaan Masyarakat. Yogyakarta : Pustaka Pelajar

[11] Wahyuni, S.H, Setyowati, S.H. 1997. Hukum Perdata I (Hukum Keluarga). Semarang: F.H. Universitas 17 Agustus (UNTAG). 